\title{
Valerio S Severino
}

\section{'CIVIL' AND 'PURELY CIVIL' IN EARLY UNIFIED ITALY - THE NATIONAL FESTIVAL FROM A JURIDICAL STANDPOINT}

Valerio S Severino, Visiting Scholar, University of Public Service, Secular Religion program, valerio.severino@uniroma1.it

The essay aims to examine the National Festival established in early unified Italy from a juridical standpoint. It intends to take a closer look at this issue by examining three prominent cases, the de-clericalisation of the Savoyard Monarchy's Constitution Day and the so-called Albertine Statute, the Italian 'Jubilee of the Fatherland', and the blessing of the flags according to military discipline. In doing so, I will address the question of the 'civil' and 'purely civil' religion.

KeYwORDS:

civil religion, civil rites, blessing of the flags, Church and State, Fatherland 


\section{DE-CLERICALISING THE STATUTE (1861-)}

The observance of a National Festival [Festa Nationale] was introduced following the proclamation of the Kingdom of Italy. The ceremony modified the previous Savoyard Monarchy's Constitution Day [Festa dello Statuto] that had celebrated, since 1851, the so-called Albertine [Carlo Alberto di Savoia's] Statute which entered into force shortly before the First Italian War of Independence. In doing so, the Albertine holiday was extended over the territories annexed to the new Kingdom 'to celebrate the Unification of Italy and the Statute' (law of 5 May 1861, Art. 1). Article 2 is evidence of the very novelty of the law - intended to abolish the rule that all the municipalities had to celebrate the Statute by 'making appropriate arrangements with the ecclesiastical authorities for the religious function.' ${ }^{1}$ By eliminating the obligation to provide the festival with a Catholic rite, the law of 1861 switched to a 'purely civil' character of the ceremony, and asserted the separation of State and Church.

The reasons that led to the de-clericalisation-secularisation of the Statute Day can be found in the speeches presenting the bill to the Senate and the Chamber of Deputies. Marco Minghetti, the Minister of the Interior appointed by the Cavour Government, stated that by the means of that 'merely civil solemnity' [solennità meramente civile] (of a 'civil and popular' character) the Government would 'implement' the 'principle of the absolute separation of Church and State' for 'the first time'. ${ }^{2}$ Furthermore, according to another speech, reasons related to 'public order' are cited to justify the decision to 'not make the participation of the ecclesiastical authorities mandatory in the Festival'. ${ }^{3}$

The law of 1861 followed the instructions addressed to the bishops by the Apostolic Penitentiary in order to avoid support of the new Government in the aftermath of the

Law of the Kingdom of Sardinia n. 1187, 5 May 1851 'Art. 1: The second Sunday of May is designated as the Festival of the Statute [Festa dello Statuto]; Art. 2. All the Municipalities of the State will celebrate the aforementioned national holiday, after making the appropriate arrangements with the ecclesiastical authorities for the religious function. The civil and military authorities, the National Guard, all the Army Corps on Land and Sea, the Teaching staff, and the Students will attend. Municipalities will allocate amounts in their budgets to be used for the festival. Our Minister Secretary of State for Interior Affairs is responsible for the execution of this Law [...]'. It is to be compared to the law of the Kingdom of Italy no. 7, 5 May 1861 'Art. 1. The first Sunday of June is designated as national holiday to celebrate the unification of Italy and the Statute of the Kingdom. Art. 2. All the Municipalities of the Kingdom will celebrate this day, having made the appropriate agreements with the Government Authorities. Art. 3. The Municipalities will allocate amounts in their budgets to be used for the celebration of the Festival. Art. 4 . All other Festivals, set by the law or by the Government at the expense of the Municipalities, cease to be compulsory.'

2 'Progetto di legge presentato il 9 aprile 1861 dal Ministro dell'Interno (Minghetti)' and 'Relazione del Ministro dell'Interno (Minghetti) 24 aprile 1861, con cui si presenta alla Camera il progetto di legge approvato dal Senato nella seduta del 20 stesso mese', in Atti del Parlamento italiano. Sessione del 1861 (VIII Legislatura). Documenti dal 18 febbraio al 23 luglio (Torino: Tipografia Eredi Botta, 1861), 218-219.

3 'Discussione del progetto di legge per l'istituzione di una Festa nazionale', in Atti del Parlamento Italiano, Sessione 1861 [session: 3 May] (Torino: Tipografia Eredi Botta, 1861), 831: Minghetti’s speech. I referred also to 'Istituzione di una nuova festa nazionale. Progetto di legge presentato il 9 aprile 1861 dal ministro dell'interno (Minghetti)', in Atti. Sessione del 1861 (VIII Legislatura). Documenti dal 18 febbraio al 23 luglio, 218. 
proclamation of the Kingdom. ${ }^{4}$ During the first years of the plebiscites, the clergymen who complied with these civil disobedience instructions were put under arrest in the Kingdom of Sardinia and in the territories annexed during Italian unification. The Sardinian Penal Code, i.e. articles 268 and 269, amended in 1859, was applied, with regard to the penalties for violation of laws of the state by the 'ministers of religion' in the performance of their duties. I refer to the cases judged in Italian courts where charges were brought against the clergymen who had refused to perform the Te Deum during the Statute Festival. ${ }^{5}$ An amnesty followed the repression, granted in September 1860 in order to foster a 'spirit of conciliation' [Conciliazione], ${ }^{6}$ of which the above mentioned law of 5 May 1861 was intended to be part. Bettino Ricasoli - Cavour's successor to the Presidency of the Council of Ministers - supported the argument that by refraining from requiring the Te Deum and implementing a 'purely civil' [puramente civile] national holiday, the freedom of both conscience and worship would be much more respected (letter to Minghetti, February 1861). ${ }^{7}$

The implementation of the law of 5 May 1861 turned out to be more puzzling than the parliamentary project, having different, even opposing purposes and, at any rate, divergent impacts. If we look at the circular of the Ministry of the Interior issued on 6 May, then it seems that a schism, not a separation from the Church, is the goal to be achieved. The fact of the matter is that the mayors and municipal authorities of the kingdom were expected to send a 'courteous invitation' [invito cortese] to the ecclesiastical authority so that they would celebrate a religious rite and attend the national holiday. ${ }^{8}$ On the one hand, disobedience of

4 Sacra Paenitentiaria Apostolici, '10 Decembris 1860', in Acta Sanctae Sedis 1 (1865-1866), 558: 'Dubia et Responsa: 1. An liceat hymnum Te Deum canere occasione proclamationis intrusi Gubernii, aut alio simili eventu. R. Negative?.

5 'Processi pei Te Deum non cantati e la libertà di coscienza', La Civiltà Cattolica 11, 7 (1860), 257-271.

6 Decree 4324, 29 September 1860. I quote from the motivation speech of the decree pronounced by the Minister of Justice and Ecclesiastical Affairs of the Kingdom of Sardinia, Giovanni Battista Cassinis: 'Spirit of conciliation of which civil society and religion benefit so much' (Gazzetta Ufficiale del Regno 233 [1860], 1).

Letter, B. Ricasoli to M. Minghetti, Firenze, 22 February 1861, in Sergio Camerani and Gaetano Arfé (eds.), Carteggi di Bettino Ricasoli. Vol. 16: 1 gennaio 1861 - 12 giugno 1861 (Roma: Istituto Storico Italiano per l'Età Moderna e Contemporanea, 1963), 146. As far as the National Day of the Statute was concerned, he stated: 'I would rather we not speak about Te Deum or ring of bells at all, and both should be forbidden, because we cannot neither admit any profanation of a temple of God, and any counterfeiting (simulazione), [...] nor should we force the ministers of the Roman Catholic church, especially nowadays, to do something against their conscience $[. .$.$] . It seems to me that it is time to stop mixing the sacristy with our Great Regeneration$ [grande rigenerazione, referring to Italian unification]. Whoever wants to go to church may freely do so, at any time and in any Church he pleases!'

8 'Circolare del Ministero dell'Interno - Festa nazionale - Esecuzione della Legge relativa, 6 maggio 1861' signed by Minghetti, in Carlo Borda (ed.), Manuale dizionario di amministrazione municipale, provinciale e delle opere pie. Guida teorico-pratica dei sindaci, vol. 1 (Torino: S. Franco e figli editori, 1863), 1289: 'You [the Mayor] are asked to send courteous invitation to the ecclesiastical authority, so that a religious rite might be performed in order to celebrate the great event that turns all the peoples of Italy into a family [...]. The Government is confident that all the Bishops and Parishes are willing to attend and will give evidence of their citizen charity (carità cittadina), on this occasion as well. If so, the religious rite, the Mass and the Ambrosian hymn [i.e. the Te Deum], will be celebrated.' The document asked to 'ascertain whether there were any churches affiliated to the municipality (di patronato municipale) in the district, and any priest willing to celebrate the festival' and 'make up for (supplire) the defection of the ecclesiastical hierarchical authority', if need be. 
the clergy to the bishops is taken to be justified, and a first step toward a Civil Constitution for the clergy was made. On the other hand, the Savoyard tradition of Church participation in civil ceremonies was resumed because the goal of dismissing it, according to the new law on the National Festival, could hardly be a one-step process and setbacks could not be avoided.

In some respects, the proposed arrangement for a 'purely civil' [purement civil according to the French rendering and Cavour's words] national festival was a substitute for a formal agreement. One step in this direction was the proposed arrangement to avoid and/or mitigate the policy of prosecutions against bishops which proved itself to be ineffective. To make his convictions on the matter clear, Cavour declared that the ministerial circular, mentioned above, and the invitation it addressed, was basically a matter of preventing - and/ or avoiding to engage in argument with - religious indifference and lack of reverence. ${ }^{9}$

The circular came under criticism in Parliament. It seemed to the Left group [Sinistra storica] that it denied the request for a 'purely and simply civil holiday', and 'absolute separation of Church and State'. To steady the turmoil caused by the circular, Minister Minghetti was asked to explain what seemed to be a 'violation' of the voted on law, as the circular and the law imposed two requirements that were almost contradictory. ${ }^{10}$ However, the explanatory report on the draft legislation had already stated that 'to those of the clergy who want to sanctify the joy of citizens with religious ceremonies, we give the credit of spontaneity' [è lasciato il merito precipuo della spontaneità]. ${ }^{11}$ On the Catholic side, the bishops stayed on their path, and continued to suspend the priests who attended the Italian Festival a divinis. ${ }^{12}$

Letter, Cavour to Vimercati, Torino, 23 May 1861; original text: French. 'The reasons which led us to assign a purely civil status to the Festival of the Statute are well known to you. Last year, the bishops who refused to celebrate religious ceremonies forced us to ensure compliance with the law, that is to say, bring them to trial, impose sentences at first, and then grant pardon as an afterthought. The law recently voted on by the Chamber of Deputies, based on our renowned principles of civil and religious freedom, set them free to either celebrate a religious function or not. To prevent, however, that this measure could be considered an example of indifference or contempt for the Ministers of the Church, Minghetti directed a circular letter to the mayors [...] with the purpose of urging the Municipalities to ask the religious authorities to join the celebration: in case of refusal the festival would be purely civil' (Commissione Reale Editrice [ed.], La questione romana negli anni 1860-1861: carteggio del Conte di Cavour con D. Pantaleoni, C. Passaglia, O. Vimercati, vol. II [Bologna: Zanichelli, 1929], 219).

10 'Interpellanza del deputato Petruccelli [Ferdinando Petruccelli della Gattina] sulla circolare del Ministro ai Vescovi relativa alla Festa nazionale e sui fatti di Milano sui fatti di Milano', in Camera dei Deputati, Sessione 1861 [session: 24 May 1861] (Roma: Botta, 1861), 1099-1100. Further pieces of evidence on the disagreement concerning the circular are collected by Giuliana d'Amelio, Stato e Chiesa. La legislazione ecclesiastica fino al 1867 (Milano: Giuffrè, 1961), 282-286.

11 'Relazione del Ministro dell'Interno (Minghetti) 24 aprile 1861', 220.

12 Maria Lupi, Il clero a Perugia durante l'episcopato di Gioachino Pecci (1846-1878) tra Stato pontificio e Stato unitario (Roma: Herder Editrice, 1998), 287; Elio Babbini, Il Cardinale Corsi di Pisa, Monsignor G. Breschi e il P. Ferdinando Giannini al Tribunale della pubblica opinione: coll'aggiunta di una lettera sulla Festa nazionale e i preti interdetti (Pistoia: Tip. Rossetti, 1863); Antonio Fappani, Il clero liberale bresciano negli anni dell'unità d'Italia (Brescia: Morcelliana, 1968), 206; Silvio Ferrari (ed.), Legislazione ecclesiastica e prassi giurisprudenziale. Gli abusi dei Ministri di culto tra laicizzazione della normativa e confessionalismo della magistratura (Padova: Cedam, 1977), 147-148. 
The ambiguity of the ministerial instructions lessened much of the novelty of the law, but, at the same time, its vagueness facilitated a quick, albeit imperfect application which succeeded in opening up a range of solutions adapted to the various territories. There was no single regulation. In Lombardy and Piedmont, in many cases, the municipalities, which had been unable to persuade any representative of the Church to attend, took the place of the clergy, no matter how a municipal council with priestly task was legally unsolicited. The representatives of the town government led the civil procession to the main church and then 'started to sing the Te Deum [...]' along 'with the councillors and the people'.13 It may have referred to a precedent, i.e. a similar 'religious demonstration, without the intervention of the clergy' reported during the Parliamentary discussion on the National Day, relating to the way the annexation of South Italy was celebrated in the city of Bra: the mayor and the Municipal council 'sang the Te Deum' with the people and 'without the involvement of a minister of religion', in a Church affiliated to the Municipality [una cappella di patronato municipale]. ${ }^{14}$

The discretionary power given to the municipalities opened the door to variations in practice. However, the custom to invite military chaplains to the National Day prevailed. An understanding of their liturgy and status - open-air mass at a field altar, i.e. in public spaces and outside churches, as they did not belong to any local diocese - makes the municipality's preference intelligible and consistent. It remained the most common practice until the suspension of the entire chaplains units in the Italian army a few years after the proclamation of the Unity of the Kingdom, already in 1867, according to peacetime rules. ${ }^{15}$ Besides, in the Italian press, since 1861, we can find claims on the 'political holiday/festival without Te Deum', or such as the allegation that the Ministry 'secularised [ha secolarizzato] the National Statute Day', and on the 'civil (non-ecclesiastical) ways of celebrating that holiday'. ${ }^{16}$

In 1861, disagreements were also expressed concerning the day of the national festival. While the day of the Savoyard 'Statute Festival' [Festa dello Statuto] was the second Sunday of May (that is the first Sunday available after 8 May, i.e. the day commemorating the opening of the first session of the Parliament of the Kingdom of Sardinia, and the entry into force of the Statute of 1848), the 'National/Italian Festival of the Statute' day was switched to the first Sunday in June. Some objections were raised regarding the month because there were no memories worth recalling in June to which all the 'peoples [popoli] of Italy' could 'connect

13 'Sacco nero', Gazzetta del Popolo 155 (6 June 1861), 5: Municipality of Sagliano.

14 'Discussione del progetto di legge per l'istituzione di una Festa nazionale', in Camera dei Deputati, Atti della Sessione del 1861, Tornata del 2 maggio (Torino: Tipografia Eredi Borra, 1861), 827: speech of Desiderato Chiaves, referring to the celebration in Bra.

15 Ilaria Porciani, 'Lo Statuto e il Corpus Domini. La festa nazionale dell'Italia liberale', Il Risorgimento. Rivista di storia del Risorgimento e di Storia contemporanea 47, 1-2 (1995), 149-173: with reference to the Decree issued on 6 January 1867.

16 'Una festa senza Te-Deum. Predica del solito Padre dell'Ordine dei Meno-Osservanti', Gazzetta del Popolo 14, 104 (14 April 1861), 2; 'Contro il Te Deum. Lettera ad Alessandro Borella di Noberto Rosa', Gazzetta del Popolo 14, 79 (20 March 1861), 4; Alessandro Borella, 'I Tiri al bersaglio', Gazzetta del Popolo 14, 116 (26 April 1861), 2-3. 
a concept' [annettere un concetto]. ${ }^{17}$ The parliamentary debate referred to the lack of a major event of historical/national significance. Even the proclamation of the King Re d'Italia (17 March 1861) was made before the territorial unification of the constitutional monarchy was completed, as the process lasted until the Plebiscite of Rome (1870). The suggestion to celebrate the Memorial Day at different times according to the region, and the day when the respective annexations to the Kingdom of Italy took place, was rejected. ${ }^{18}$ What is more, the arrangements succeeded in changing the month of the Statute Festival but not the day, while the issue of the feast's being celebrated on a (Christian) Sunday underwent no discussion in Parliament.

The historian Ilaria Porciani remarked on the interference between the Italian constitutional and the Catholic Eucharistic holy days. Being celebrated on the first Sunday of June, the National Festival greatly competed with the liturgical calendar, i.e. the Corpus Domini. The two movable feasts, civil/national and religious/Catholic became two 'poles' of an 'oppositional couple' - according to Porciani's words - and informed a conflict of symbols, Festivals and rivalling demands for consensus. ${ }^{19}$ A new approach to this issue may point out, however, that the Italian law brought the national and religious holidays closer together, and one conclusion that might be drawn from it is that by aiming to keep a connection, the law of 1861 was a matching experiment, if not a procedure of reconciliation. That is not to say that the couple 'Statute Festival (at the beginning of the Italian state) and Corpus Domini (at the end of the Papal States)' did not entail a dual system and even clashing solutions. But, in my view, the challenge to not move in the direction of greater polarisation, and to reduce the risk of division into two sharply unrelated opposites having higher collision potential, is remarkable. It is revealing how the law on the national holiday was also implemented by monitoring formal refusals by municipal officers to attend the Corpus Domini procession. ${ }^{20}$ Both suspensions from the exercise of their office and resignations in protest over this obligation occurred ${ }^{21}$ and both are to be considered.

17 'Discussione del progetto di legge per l'istituzione di una Festa nazionale', in Camera dei Deputati, Sessione del 1861, Tornata del 3 maggio (Torino: Tipografia Eredi Borra, 1861), 826: Chiaves's speech.

18 'Discussione del progetto di legge per l'istituzione di una Festa nazionale', Tornata del 3 maggio, 832-833: Alfieri's speech.

19 Pier Giorgio Camaiani, 'Motivi e riflessi religiosi della questione romana', in [Multiple authors], Chiesa e religiosità in Italia dopo l'Unità (1861-1878). Relazioni II (Milano: Vita e Pensiero, 1973), 105-106; Maurilio Guasco, Storia del clero in Italia dall'Ottocento a oggi (Roma-Bari: Laterza, 1997), 73-77; Ilaria Porciani, Lo Statuto e il Corpus Domini, 151-154; Maurizio Ridolfi, Le feste nazionali (Bologna: Il Mulino, 2003), 34-37.

20 'Questione di logica', Gazzetta del Popolo 14, 142 (1861), 3; 'Sacco nero', Gazzetta del Popolo 14, 144 (1861), 5: referring to the 'priests' who 'have no nation' and no 'National Festival', opposing the idea of providing them with a 'civil power' which is not provided by the Corpus Domini procession. A. B., 'Genova 25 maggio ci scrivono', Gazzetta del Popolo 14, 146 (1861), 4: the municipal committees [Genoa] approved to 'not attend the incoming Corpus Domini procession'.

${ }_{21}$ Two recorded instances of resignations: in Florence (Gazzetta del Popolo 14, 169 [1861], 5 [20 June]; and Savona ('Notizie italiane', Gazzetta del Popolo 150 (1 June 1861), 5. In many cases, the Italian protests were against the military participation to the Corpus Domini procession (e.g. 'Sacco nero', Gazzetta del Popolo 149 [1861], 4). 


\section{THE 'JUBILEE OF THE FATHERLAND' (1911-)}

The Italian Kingdom holiday reached a turning point in the management of the festival in 1911, at the grand opening of the Pater Patriae memorial in Rome, eventually called the Vittoriano monument, and hosting the Altar of the Fatherland [Altare della Patria]. From here on, the national narrative seems to comply more with patterns of sacralisation than de-clericalisation of the Statute and/or nationalisation of the clergy, i.e. the processes implemented since 1861. This reading - according to which the monument and the 1911 ceremony are both products of a 'process of education to believe in the holiness of the nation' at the apex of the 'rhetoric of the sacred' and 'patriotic liturgies' performed in the fiftieth anniversary of the Kingdom - is acknowledged by historians of the Risorgimento culture, e.g. Alberto Mario Banti. ${ }^{22}$ The appeal of this rhetoric is noteworthy in 1911: in his speech delivered at the inaugural ceremony of the Jubilee, the Mayor of Rome, Ernesto Nathan, elaborated his views on the 'altar of the fatherland' publicly. ${ }^{23}$ But other aspects, related to secularisation, must not be overlooked.

The main National Day ceremony, in 1911, held at the memorial dedicated to King Vittorio Emanuele II, was performed according to the practices of the Festival promoted since 1861. The rite consisted of different elements, which included the handing over of the national flag to military units, followed by the oath of allegiance. ${ }^{24}$ I will examine the processions of the army flags - intended to be perceived as traditional, and initiate a national memory by recalling the wars of independence - in the next paragraph in more detail.

The novelty of the festival can be found in the procession of the mayors gathered in Rome, which allocated a new form of participation to the clergy. Six thousand Italian mayors went up the stairs of the building of the Altar of the Fatherland, ritually. The ceremony of the 'ascent' of the mayors involved a 'mayor/patriot priest [...] wearing a Roman cassock and the national sash', in the presence of the 'parliamentary Catholic group'; a 'church minister [sacerdote] mayor' (I quote from the Giornale d'Italia, La Stampa and Il Messaggero [newspaper] reports). ${ }^{25}$ The name of that mayor is not released, but news were circulating that he came 'from Sicily' (La Stampa and Corriere della Sera), or more generically from the 'southern provinces' (L'Osservatore Romano) or specifically that he was the 'mayor [...] of Caltagirone' [Avanti!]. ${ }^{26}$ Recent studies attempted to demonstrate that Luigi Sturzo, who

22 Alberto Mario Banti, Sublime madre nostra: la nazione italiana dal Risorgimento al fascismo (Roma-Bari: Laterza, 2011): the paragraph: Altari sacrificali.

23 Municipio di Roma, S.P.Q.R.: 27 marzo 1861, 27 marzo 1911 (Roma: Tipografia Editrice Nazionale, 1911), 318.

$24 \quad$ 'Festa nazionale in Firenze', and 'Festa nazionale in Torino', Gazzetta del Popolo 123, and 124 (3 June and 4 June 1861), 1-2, 2 .

25 'Il prete sindaco ama il Re e il Papa', Il Giornale d'Italia, 8 June 1911, 4; 'Caratteri e significato di una giornata storica', La Stampa, 5 June 1911, 2; 'Il sindaco sacerdote', Il Messaggero, 6 June 1911, 1.

26 'I Sovrani d'Italia inaugurano in Roma il monumento al Gran Re', La Stampa, 5 June 1911, 1; 'Il monumento al Padre della Patria inaugurato stamane a Roma dai Sovrani', Corriere della Sera, 4 June 1911, 7; 'Un sacerdote fuori posto', L'Osservatore Romano, 5 June 1911, 3; 'L'inaugurazione del monumento' and 'Un simbolo', Avanti! Giornale del Partito Socialista, 5 June 1911, 1. 
will found the Italian Christian Democratic Party [Partito Popolare], is the 'mayor priest' mentioned in the newspapers, by referring to the fact that Sturzo, mayor of Caltagirone, was in Rome at the time of the National Festival in order to attend the Roman congress of the National Association of Italian Municipalities $[\mathrm{Anci}] .^{27}$ In the days immediately following the ceremony, the priest figure was identified as Giulio Paolucci, mayor of Abruzzo (central-southern Italy), ${ }^{28}$ which turns out to be misguided information when this data concerning his provenance is compared with the other ones mentioned above. This does not, however, rule out that two (or more) mayor priests had climbed the national monument in June 1911. If any error has been made in referring to Sturzo, the similarity between the two priest mayors is to be acknowledged.

In the aftermath of the Fascist era, Sturzo's statement concerning the Altar of the Fatherland memorial - described as the symbol of the 'complete fiasco' of the 'liberal governments' - looks quarrelsome, in speaking of the relationship between State and Church in Italy. ${ }^{29}$ Quite understandably, the political context in 1946 changes the criteria on which he might have based his judgment, compared to the earlier situation, that is the National Festival held in 1911 - whether he had attended or not. In 1911, Sturzo was in the middle of a process whose outcome and premise were far from leading to the sacralisation of a political party and the state, i.e. between the birth of the Partito Popolare (founded in 1919), and the Italian Catholic Electoral Union (UECI, established in 1906), following the encyclical of Pope Pius X on the 'Catholic Action'/'lay Catholics' in Italy issued with regard to the 'duty on all Catholics to prepare themselves prudently and seriously for political life' (Il Fermo proposito, issued in 1905), i.e. actions which were intended to implement a secularisation of the clergy and not a sacralisation of politics. Shortly after the Festival held in 1911, the new Union advanced into a more developed stage, i.e. the secret alliance between Prime Minister Giovanni Giolitti and the UECI, chaired by V. O. Gentiloni, supported in view of the 1913 Italian general election, which marks an experiment of improvement of the Catholic faction in the Liberal party [Unione Liberale]. Both the inclusion of priests in the mayors' procession at the National Festival in 1911 and the 'Gentiloni Pact' are two complementary aspects of the same process of secularisation/

27 Giuseppe Spataro, I democratici cristiani dalla dittatura alla Repubblica (Milano: Mondadori, 1968), 16; Paolo Emilio Taviani, 'Filippo Meda e il cinquantenario di Civitas', Civitas. Rivista mensile di studi politici 21, 5 (1970), 3-12, 7; Umberto Chiaramonte, Luigi Sturzo nell'ANCI (Soveria Mannelli: Rubbettino, 2004), 149, note 328; and 45. To the best of my knowledge, the involvement of a priest in the rites of the Altar of the Fatherland in Rome went unnoticed by the historians of the Vittoriano memorial, with few exceptions (Bruno Tobia, L'Altare della Patria (Bologna: Il Mulino, 2011 [1st ed. 1998]), 14: who made no attempt to identify him).

28 Giulio Paolucci, mayor of Goriano Sicoli (Aquila): 'Il monumento a Vittorio Emanuele II e all'Unità italiana', Il Messaggero, 5 June 1911, 1; 'Il sindaco sacerdote', 1; 'Il prete sindaco ama il Re e il Papa', Il Giornale d'Italia, 8 June 1911, 4; 'Un sacerdote fuori posto', 3.

29 Luigi Sturzo, Nazionalismo e internazionalismo (Bologna: Zanichelli, 1971 [1st ed. 1946]), 66: the memorial revealed itself to be 'an intruder within the walls of Rome', instead of 'marking the beginning of a national greatness'. A clip of the following newspaper article is preserved in Sturzo's Archives (Fondazione Luigi Sturzo, Rome) 'Lapoteosi dell'unità d'Italia nella cerimonia inaugurale del monumento a Vittorio Emanuele sul Campidoglio', Corriere della Sera, 5 June 1911. 
inclusion of Catholicism in Italian political life at the time. Both are of concern in the so-called 'silent conciliation', twenty years before the Lateran Pacts signed by Mussolini. ${ }^{30}$

Still another aspect should be considered. In 1911, a few days after the National Festival, several incidents during the Corpus Domini processions were reported, notably by the L'Osservatore Romano, i.e. alleged aggression by socialist and anticlerical groups. On 15 June, in Fabriano, protesters ran over the bishop holding the Blessed Sacrament; in Fano, an attempt was made 'to tear down the processional canopy under which the Blessed Sacrament stood'. ${ }^{31}$ These do not appear to be isolated incidents, but a long established practice $^{32}$ varying to a greater or lesser extent, and to a greater or lesser extent exploited by both the Catholic press, by magnifying the occurrences, and the Italian Municipalities, that referred to reasons related to public order to justify the prohibition on procession outside churches. Incursions into churches by demonstrators, and law enforcement by security forces are reported, as well. ${ }^{33}$

The range of cases partially examined above is not meant to be exhaustive, but concentrates on some instances that prove most useful in the analysis of the civil versus religious conflict. It is to be noted, however, that there was no religious issue in the Italian ceremonies in the sense that any Italian government was dedicated to the preservation of Catholic holidays in the civil calendar. The Corpus Domini ['S.mo Corpo di Cristo'] was included in the list ['Tabella'] of the holidays ['giorni festivi'] entitled to the benefit of the civil effects [effetti civili], i.e. the 'Calendar of the holidays' which had been in use since 1853 in the Kingdom of Savoy Piedmont-Sardinia, and then officially introduced in the Kingdom of Italy, too, since 1869 (according to the Royal Decree n. 5342, 17 October). A peculiar aspect of the Italian civil calendar is that the 'civil effects' of the Catholic holidays were never called into question even after the 'purely civil' reform, not even in the course of several parliamentary debates related to the 1869 law and the new regulation

30 Giovanni Spadolini, Giolitti e i cattolici (1901-1914). La conciliazione silenziosa (Firenze: Edizioni della Cassa di Risparmio di Firenze, 1990 [1st ed. 1959]); Processo all'Altare della Patria. Atti del processo al monumento in Roma a Vittorio Emanuele II, ed. by Vanni Scheiwiller (Roma: Libri Scheiwiller, 1986), 25.

31 'La teppa anticlericale di Fabriano assalta la processione del Corpus Domini', L'Osservatore Romano, 17 June 1911, 2; 'Gli anticlericali di Fano contro una processione', L'Osservatore Romano, 20 June 1911, 3; 'Disordini provocati dagli anticlericali durante la precessione del Corpus domini a Fabriano', La Domenica del Corriere, 25 June 1911.

32 Further examples: [no identified author], Tumulti in Firenze la sera del 6 giugno 1861: Ottava del Corpus Domini (Firenze: Tip. della Minerva, 1861); 'La processione del Corpus Domini a Siena; insulti alla religione in Lucca', La Civiltà Cattolica 14, 7 (1863), 365: Siena and Lucca 1863; Salvatore Randazzini, Perchè i rivoluzionari vogliono andare a Roma: autorità e testimonianze (Milano: Tip. e Libr. Arcivescovile G. Agnelli, 1869), 39: Montechiari 1862; Venezia and Verona 1867; Gustavo Frigyesi, L'Italia nel 1867: storia politica e militare corredata di molti documenti editi ed inediti e di notizie speciali. Vol. I (Firenze: Tip. di G. Pellas, 1870), 413-414: Verona 1867; 'Laggressione contro i cattolici di Genova', La Civiltà Cattolica 36, 11 (1885), 107-110: Genova 1885. Fortunato Iozzelli, Roma religiosa all'inizio del Novecento (Roma: Edizioni di Storia e Letteratura, 1985), 308-309: Rome (Testaccio district 1911, Aurelia street 1912).

33 Nicola De Crescenzio and Enrico Scialoja (eds.), Il Foro italiano: raccolta generale di giurisprudenza civile, vol. 9 (Roma: Foro Italiano, 1884), 18-22 (Palermo 1883); 'Cronaca, cose italiane', La Civiltà Cattolica 10 (1879), 247 with reference to the Corpus Domini. 
entering into force in 1874 (law n. 1968) and 1895 (law n. 401), by adding respectively that New Year's Day and the day of the $20^{\text {th }}$ of September [Italian Capture of Rome] (to be celebrated as a "national festival [Festa nazionale]"), in the list of the civil holidays. Only in 1913 a 'reduction of the civil holidays' was suggested. On the one hand, such a reduction was intended to conform to the Catholic calendar, i.e. to follow the adjustment made in 1911 by Pius X who reduced the number of Holidays of Obligation (from 36 to 8, Motu proprio "Supremi Disciplinae" on 2 July 1911). The amendment of the Italian calendar was most readily justified on this basis by the Minister of Justice and Cult, i.e. on the ground that it included holidays which 'not even ecclesiastically entail a suspension of work, any longer'34 notably the Corpus Domini. Very little or no attention to such a reduction was paid in the Parliament, until the reform of the ecclesiastical calendar. On the other hand, the law on the 'reduction of the civil holidays' (n. 630 [19 June 1913] and R. Decree 4 August 1913 n. 1027) ${ }^{35}$ created a new long-standing inconsistency, ${ }^{36}$ as it affected the Assumption of the Blessed Virgin (15 August) and the feast of Saints Peter and Paul (29 June), which were not excluded by the Supremi Disciplinae.

\section{THE BLESSING OF THE FLAGS ACCORDING TO MILITARY DISCIPLINE}

Since evidence for the analysis of the National Festival in early unified Italy emphasises the role of flags in the rite, in this paragraph I will turn to the tradition of the procession of flags that had developed as a civil symbol exhibition, and established its own Festival [Festa delle Bandiere].

In 1913, the monument hosted a flags exhibition of the regiments engaged in the ItaloTurkish campaign. The military flags performance, already included as a part of the National Festival, became the main focus. They were gathered in Rome, carried in a procession climbing the stairs of the Altar of the Fatherland. ${ }^{37}$ At the 24 May 1916 commemoration,

34 Camillo Finocchiaro Aprile (Ministro di Grazia e Giustizia e dei Culti), 'Riduzione delle feste civili. Disegno di Legge approvato dal Senato del Regno. Seduta del 4 giugno 1913', in Camera dei Deputati, Atti Parlamentari, Documenti. Disegni di Legge e relazioni, sess. 1909-1913, vol. 32, n. 1439 (Roma: Tipografia della Camera dei Deputati, 1913), 1: 'La presente determinazione delle feste civili [...] risale a disposizioni emanate dallo Stato Sardo, e comprende tuttora nel novero delle feste civili alcune ricorrenze di carattere religioso le quali, in seguito al motu proprio pontificio del 2 giugno [sic! July] 1911, neanche ecclesiasticamente importano più l'astensione dal lavoro.' Similar arguments in the newspapers, e.g. 'La riduzione delle feste civili', La Provincia di Pisa 41, 23 (1913), 1; 'La riduzioni delle feste civili. Il nuovo disegno di legge', Il Messaggero, 1 June 1913, 2.

35 Gazzetta Ufficiale 145 (23 June 1913): 'Tutte le domeniche; il primo giorno dell'anno; il giorno dell'Epifania; dell'Ascensione; dell'Assunzione; del Venti Settembre; di Ognissanti; di Natale'.

36 Remarks in this regard in 'Cronaca contemporanea. Cose Italiane', La Civiltà Cattolica 75, 1 (1924), 278 with reference to L'Osservatore Romano, 17 January 1924. The discrepancy between the civil and religious calendars increased when the Church resumed the Corpus Domini Day in the 1917 Code of Canon Law.

37 'I soldati d'Italia ricompensati dal Re sull'altare della Patria tra l'esultanza del popolo. Giornata degna di Roma', La Stampa, 20 January 1913, 1; 'Il re premia sul Campidoglio le bandiere vittoriose dopo aver passato in rivista le truppe che combattevano in Libia, Il Messaggero, 20 January 1913, 1. 
the aesthetics of the 'city with flag' [città imbandierata] was applied..$^{38}$ On 4 November 1920, the second anniversary of the Italian World War I Victory (before the institution of the Unknown Soldier), a 'Festival of Flags' [Festa delle Bandiere] was performed which replicated the 1913 program mentioned above, i.e. the gathering of flags in Rome, despite significant variations in ritual practice, including the Catholic mass at the Quirinale (King residence in Rome) celebrated by the court chaplain surrounded by the national flags. ${ }^{39}$

In the Statute Day/National Festival and the World War I celebrations, flags were constantly in evidence while the ceremonies performed on the Altar of the Fatherland changed. In addition to this obvious feature of the rites of flags revealing continuity, less apparent issues are also important evidence of 'purely civil' deficiencies. Among these, there are inadequacies, such as the agreements on the blessing of the flags by ecclesiastical authorities, to which I will turn in the following pages. This section seeks to highlight the inconsistency between the claim of a separation of Church and State in civil rites and the prevailing use of flags over which public officials are expected to receive instructions from ecclesiastical authorities. To the best of my knowledge, this inconsistency was obscured at the time, deliberately, also in the scholarly debate. It deserves greater consideration than it is currently receiving.

A note issued by the Ministry of War dated 29 May 1862 (n. 82) stated that the blessing of the flags should be performed by military chaplains. ${ }^{40} \mathrm{~A}$ handbook of Military Discipline for the National Guard from 1863 provides instructions on the Catholic mass and blessing of the troops (how the soldiers get in line in the church and in front of the altar, how the movements of the weapons are to be performed during the Elevation [part three, Art. II]). ${ }^{41}$ The regulation of military discipline for the Navy corps, ratified by the Royal Decree on 11 March 1865, provides for the chaplain's blessing of the new recruits who swear their oath using the formula 'in the presence of God' and in front of the flag (Art. 226). ${ }^{42}$

In 1885, the Minister of War replied to a parliamentary question on the negotiations between the governmental and ecclesiastical authorities for the blessing of the flags of the new regiments of the 'Rome' Brigade [Brigata Roma]. The Government found leverage to be in a position to 'modify' (i.e. revoke) the 'old' regulation on the military ceremony

38 'La commemorazione del XXIV maggio a Roma e in Italia', Il Messaggero, 25 May 1916, 3.

39 Alessandro Miniero, Da Versailles al Milite ignoto: rituali e retoriche della vittoria in Europa (1919-1921) (Roma: Gangemi, 2008), 114; Maurizio Ridolfi, Le feste nazionali, 150-153. 'Le bandiere della Vittoria consacrate al Quirinale', Il Giornale d'Italia, 4 November 1920, 2.

40 Orazio Viola, Il tricolore italiano. Saggio bibliografico (Catania: Libreria Editrice C. Battiato, 1905), IV: 'Ministero della Guerra', Note n. 82 (29 May 1862): 'Ministro della Guerra, Segreteria Generale, Divisione Giustizia e Istituti militari, sez. $2^{\circ}$; Giovanni Battista Brignardello, Per la solenne benedizione della bandiera e giuramento della Guardia Nazionale di Teramo: parole lette nella cattedrale della città li 6 aprile 1862 (Chieti: Q. Scalpelli, 1862).

${ }^{41} \quad$ Ferdinando Nocenti (ed.), Prontuario di disciplina militare per uso della guardia nazionale mobile e sedentaria che servir può anche per l'armata, ossia, doveri generali e speciali dei militi e sott'ufficiali. Vol. 3: Alcuni servizi di quartiere e di piazza (Assisi: Tip. di D. Sensi, 1863), 2-3.

42 'Regio Decreto col quale è approvato il Regolamento di disciplina militare per i Corpi della R. Marina, n. 1605 marzo 1865', Leggi e Decreti del Regno d'Italia. Parte supplementare 5 (1865), 207. 
which 'must' [deve] combine delivery to the regiments and blessing of the new flags. ${ }^{43}$ The blessing rite should have been performed on the day of the foundation stone ceremony of the 'Vittorio Emanuele II' memorial in Rome (Vittoriano/Altar of the Fatherland), on 14 March. ${ }^{44}$ Both ceremonies were postponed, the first on 16 March, the latter on $22 \mathrm{March}$, in order to not overlap. It is a fact neglected in the scholarly debate on the history of the memorial, which illustrates the separation of the blessing of the flags (related to a regiment of Rome) and the memorial ceremony (held without the clergy and referred to by Prime Minister Agostino Depretis as the 'national religion' [Religione nazionale]). ${ }^{45}$

The military regulation of the Catholic blessing will be implemented, while the representation of the Italian flag 'of the revolution that ousted the Pope' [che ha spodestato il Papa], belonging to a kind of secular religiosity (the 'blessing [...] by the people'), remained a vocal minority. ${ }^{46}$ According to Catholic sources, from the capture of Rome to the end of the nineteenth century, the blessing of the flags of the Italian army would have been performed in Rome only three times. ${ }^{47}$

In 1887, the Congregation of Rites of the Roman Curia forbade the clergy to allow flags that were not blessed to be introduced into churches..$^{48}$ This provision particularly affected private associations, e.g. labourer's associations, and in most cases prohibited funeral processions of their members from entering the church with the flag, while national flags were allowed, such as those of the army, because they were blessed; but, however blessed they might be, they might not be introduced by non-Catholic people or associations. In the following years, the Ministry of Justice raised the question if such misconduct should not be reported as a matter of criminal offence and should not be dealt with under the discipline code related to 'flag desecration', or violation of the flag protocol, by investigating on the 'various forms' of the ecclesiastical prohibition and evaluating the urgency of a clarification also on the basis of the Italian Penal [Zanardelli] Code in effect since 1890 (Art. 115 and 182). ${ }^{49}$ The flag issue was raised in the Chamber of Deputies several times, e.g. in 1899, with reference to an accident in Rome at the Church of S. Andrea delle Fratte 'where the national flag was rejected and torn' [respinta e stracciata]. The undersecretary of the Ministry of Justice referred to the Council of State which stated the 'illegitimacy of the rejection

43 'Annunzio e svolgimento di una domanda d'interrogazione del deputato Comin- Ricotti, Ministro della Guerra, intervento' [session: 16 March 1885], in Camera dei Deputati, Atti Parlamentari, Legislatura XV (Roma: Tip. della Camera dei Deputati, 1885), 12914-12915.

44 'La benedizione delle bandiere', La Tribuna, 15 March 1885, 1; 'La benedizione delle bandiere', La Tribuna, 17 March 1885, 2; 'Dispacci particolari del Roma, Roma 16', Roma. Giornale politico quotidiano 24, 75 (1885), 3.

45 'Cronaca contemporanea. Cose italiane', La Civiltà Cattolica 36, 10 (1885), 109-112, 238-239; 'Il discorso dell'on. Depretis', La Tribuna, 24 March 1885, 2; 'Re Vittorio All'Aracoeli', Il Messaggero, 23 March 1885, 3; 'Cronaca cittadina. La funzione di ieri', L'Osservatore Romano, 24 March 1885, 2; 'Cronache di Roma. Sul Colle capitolino', La Tribuna, 23 March 1885, 2.

46 Luigi Mostardi, 'La benedizione delle bandiere', Il Messaggero, 13 March 1885, 1.

47 Salvatore Brandi, 'Le bandiere in chiesa', La Civiltà Cattolica 49, 1 (1898), 261.

8 Il monitore ecclesiastico. Pubblicazione mensuale ad uso del clero 8 (1893), 263.

49 Document from the archives of the Ministry of the Interior, 10 December 1898, available in Silvio Ferrari (ed.), Legislazione ecclesiastica e prassi giurisprudenziale, 213. 
of national flags', and pointed out a loophole in the law addressing the flag protocol and, as far as the distinction of a private or public national flag is concerned, the technical defect of the laws in mentioning the national flag with regard to the royal banners, Army flags, Military and Merchant Navy flags only. ${ }^{50}$

At the end of the nineteenth century, the Regulations for territorial service (vol. V, chap. 2) still provided for the blessing of the military flag inside a church or at an open-air field altar and arranged for it to be unfolded before the priest by the army official and then turned to the soldiers for the oath. ${ }^{51}$ In 1907, the Military Discipline Regulation, approved by the R. D. issued on 25 July, provides us with documents on the enduring flag blessing ceremony and on the regiment's oath (appendix, vol. I, Art. 113): 'The captain [...] turns it [the flag] to the priest so that he can bless it'; and the oath formula: 'Religion has now blessed the flag. ${ }^{52}$

\section{CONCLUSIONS}

Further research would be required to provide a better understanding of the diverging practices of the flag blessing ceremonies. But these issues remain unclear: the value of the 'blessing of flags' tradition if the new purely civil project could not survive with it; the benefits of flag performances for this project; the contradictory nature of the two requirements both of concern to the National Festival and its two above mentioned processions: the need for a far greater secularisation of clergymen, and the need for a far greater sacralisation of the flags, as well as the real issues actually addressed in the early unified Italy while governments endorsed hidden church-state cooperation.

50 Camera dei Deputati, Atti Parlamentari, vol. LXXXVIII (Roma: Tip. della Camera dei Deputati, 1899), 3111-3112: (18 March 1899 session: Massimo Bonardi’s speech, Incidente di una bandiera): 'Dinanzi a questa lacuna delle nostre leggi parve al Consiglio di Stato che il fare distinzioni fra bandiere nazionali pubbliche e private non fosse conveniente ed opportuno, e ritenne che tutte le bandiere così di corpi costituiti come di associazioni private debbano essere considerate alla stessa guisa di fronte alle pretese della Chiesa, ma dichiarava illegittimo e punibile nell'autorità ecclesiastica soltanto il rifiuto della bandiera nazionale perché tale $[\ldots]$ '.

51 Michele Della Cella, 'Bandiera, Digesto Italiano, vol. V (Torino: Utet, 1890), 247; Gregorio Carbone, 'Benedizione della bandiera', in Dizionario militare compilato e dedicato alla maestà di Vittorio Emanuele II. Re d'Italia, ed. by Gregorio Carbone (Torino: Tip. V. Vercellino, 1863), 534.

52 Regolamento di disciplina militare per il R. Esercito. Edizione 1907 (Milano: Ditta Tip. Ed. Libraria L. di G. Pirola, 1927; and the 1922 edition including the new regulation of 1909), 195-196, 533, 536. 


\section{REFERENCES}

Italian laws and parliamentary debates

1. 1851 - Law of the Kingdom of Sardinia 'Festa dello Statuto da celebrarsi annualmente nella seconda Domenica di maggio' n. 1187, 5 May.

2. 1861 - 'Progetto di legge presentato il 9 aprile 1861 dal Ministro dell'Interno (Minghetti)' and 'Relazione del Ministro dell'Interno (Minghetti) 24 aprile 1861, con cui si presenta alla Camera il progetto di legge approvato dal Senato nella seduta del 20 stesso mese', in Atti del Parlamento italiano. Sessione del 1861 (VIII Legislatura). Documenti dal 18 febbraio al 23 luglio (Torino: Tipografia Eredi Botta, 1861).

3. 1861 - 'Discussione del progetto di legge per l'istituzione di una Festa nazionale', in Atti del Parlamento Italiano, Sessione 1861 [session: 3 May] (Torino: Tipografia Eredi Botta, 1861).

4. 1861 - Legge per l'instituzione di una festa nazionale, n. 7, 5 May.

5. 1861 - 'Interpellanza del deputato Petruccelli [Ferdinando Petruccelli della Gattina] sulla circolare del Ministro ai Vescovi relativa alla Festa nazionale e sui fatti di Milano sui fatti di Milano', in Camera dei Deputati, Sessione 1861 [session: 24 May 1861] (Roma: Botta, 1861).

6. 1865 - 'Regio Decreto col quale è approvato il Regolamento di disciplina militare per i Corpi della R. Marina, n. 1605 marzo 1865', Leggi e Decreti del Regno d'Italia. Parte supplementare 5 (1865).

7. 1885 - 'Annunzio e svolgimento di una domanda d'interrogazione del deputato Comin Ricotti, Ministro della Guerra, intervento' [session: 16 March 1885], in Camera dei Deputati, Atti Parlamentari, Legislatura XV (Roma: Tip. della Camera dei Deputati, 1885).

8. 1899 - Camera dei Deputati, Atti Parlamentari, vol. LXXXVIII (Roma: Tip. della Camera dei Deputati, 1899), 3111-3112 (session: 18 March 1899).

9. 1907-1909 - Regolamento di disciplina militare per il R. Esercito. Edizione 1907 (Milano: Ditta Tip. Ed. Libraria L. di G. Pirola, 1927; and the 1922 edition including the new regulation of 1909).

10. 1913 - 'Riduzione delle feste civili. Disegno di Legge approvato dal Senato del Regno. Seduta del 4 giugno 1913', in Camera dei Deputati, Atti Parlamentari, Documenti. Disegni di Legge e relazioni, sessione 1909-1913, vol. 32, n. 1439 (Roma: Tipografia della Camera dei Deputati, 1913).

Journals (no identified author's articles)

1. 'Caratteri e significato di una giornata storica'. La Stampa, 5 June 1911.

2. 'Contro il Te Deum. Lettera ad Alessandro Borella di Noberto Rosa'. Gazzetta del Popolo 14, 79 (1861).

3. 'Cronache di Roma. Sul Colle capitolino'. La Tribuna, 23 March 1885.

4. 'Cronaca cittadina. La funzione di ieri'. L’Osservatore Romano, 24 March 1885.

5. 'Cronaca contemporanea. Cose italiane'. La Civiltà Cattolica 36, 10 (1885). 
6. 'Cronaca contemporanea. Cose Italiane’. La Civiltà Cattolica 75, 1 (1924).

7. 'Cronaca, cose italiane'. La Civiltà Cattolica 10 (1879).

8. 'Disordini provocati dagli anticlericali durante la precessione del Corpus domini a Fabriano'. La Domenica del Corriere, 25 June 1911.

9. 'Dispacci particolari del Roma, Roma 16'. Roma. Giornale politico quotidiano 24, 75 (1885).

10. 'Festa nazionale in Firenze'. Gazzetta del Popolo 14, 123 (1861).

11. 'Festa nazionale in Torino'. Gazzetta del Popolo 14, 124 (1861).

12. 'Genova 25 maggio - ci scrivono'. Gazzetta del Popolo 14, 146 (1861).

13. 'Gli anticlericali di Fano contro una processione'. L'Osservatore Romano, 20 June 1911.

14. 'I soldati d'Italia ricompensati dal Re sull'altare della Patria tra l'esultanza del popolo. Giornata degna di Roma'. La Stampa, 20 January 1913.

15. 'I Sovrani d'Italia inaugurano in Roma il monumento al Gran Re'. La Stampa, 5 June 1911.

16. 'I Tiri al bersaglio'. Gazzetta del Popolo 14, 116 (1861).

17. 'Il discorso dell'on. Depretis'. La Tribuna, 24 March 1885.

18. 'Il monumento a Vittorio Emanuele II e all'Unità italiana'. Il Messaggero, 5 June 1911.

19. 'Il monumento al Padre della Patria inaugurato stamane a Roma dai Sovrani'. Corriere della Sera, 4 June 1911.

20. 'Il prete sindaco ama il Re e il Papa'. Il Giornale d'Italia, 8 June 1911.

21. 'Il re premia sul Campidoglio le bandiere vittoriose dopo aver passato in rivista le truppe che combattevano in Libia'. Il Messaggero, 20 January 1913.

22. 'Il sindaco sacerdote'. Il Messaggero, 6 June 1911.

23. 'La benedizione delle bandiere' [by Luigi Mostardi]. Il Messaggero, 13 March 1885.

24. 'La benedizione delle bandiere'. La Tribuna, 15 March 1885.

25. 'La commemorazione del XXIV maggio a Roma e in Italia'. Il Messaggero, 25 May 1916.

26. 'La processione del Corpus Domini a Siena; insulti alla religione in Lucca'. La Civiltà Cattolica 14, 7 (1863).

27. 'La riduzione delle feste civili'. La Provincia di Pisa 41, 23 (1913).

28. 'La riduzioni delle feste civili. Il nuovo disegno di legge'. Il Messaggero, 1 June 1913.

29. 'La teppa anticlericale di Fabriano assalta la processione del Corpus Domini'. L'Osservatore Romano 17 June 1911.

30. 'L'aggressione contro i cattolici di Genova'. La Civiltà Cattolica 36, 11 (1885).

31. 'L'apoteosi dell'unità d'Italia nella cerimonia inaugurale del monumento a Vittorio Emanuele sul Campidoglio'. Corriere della Sera, 5 June 1911.

32. 'L'inaugurazione del monumento' and 'Un simbolo'. Avanti! Giornale del Partito Socialista, 5 June 1911.

33. 'Le bandiere della Vittoria consacrate al Quirinale'. Il Giornale d'Italia, 4 November 1920.

34. 'Le bandiere in chiesa' [by Salvatore Brandi]. La Civiltà Cattolica 49, 1 (1898).

35. 'Notizie italiane'. Gazzetta del Popolo 14, 150 (1861). 
36. 'Processi pei Te Deum non cantati e la libertà di coscienza'. La Civiltà Cattolica 11, 7 (1860).

37. 'Questione di logica'. Gazzetta del Popolo 14, 142 (1861).

38. 'Re Vittorio All'Aracoeli'. Il Messaggero, 23 March 1885.

39. 'Sacco nero'. Gazzetta del Popolo 14, 149 (1861).

40. 'Sacco nero'. Gazzetta del Popolo 14, 155 (1861).

41. 'Un sacerdote fuori posto'. L'Osservatore Romano, 5 June 1911.

42. 'Una festa senza Te Deum. Predica del solito Padre dell'Ordine dei Meno-Osservanti'. Gazzetta del Popolo 14, 104 (1861).

\section{Authors and editors}

1. Babbini, Elio, Il Cardinale Corsi di Pisa, Monsignor G. Breschi e il P. Ferdinando Giannini al Tribunale della pubblica opinione: coll'aggiunta di una lettera sulla Festa nazionale e i preti interdetti. Pistoia: Tip. Rossetti, 1863.

2. Banti, Alberto Mario, Sublime madre nostra: la nazione italiana dal Risorgimento al fascismo. Roma-Bari: Laterza, 2011.

3. Borda, Carlo (ed.), Manuale dizionario di amministrazione municipale, provinciale e delle opere pie. Guida teorico-pratica dei sindaci, vol. 1. Torino: S. Franco e figli editori, 1863.

4. Brignardello, Giovanni Battista, Per la solenne benedizione della bandiera e giuramento della Guardia Nazionale di Teramo: parole lette nella cattedrale della città li 6 aprile 1862. Chieti: Q. Scalpelli, 1862.

5. Camaiani, Pier Giorgio, 'Motivi e riflessi religiosi della questione romana', in [Multiple authors], Chiesa e religiosità in Italia dopo l'Unità (1861-1878). Relazioni II. Milano: Vita e Pensiero, 1973.

6. Camerani, Sergio and Gaetano Arfé (eds.), Carteggi di Bettino Ricasoli. Vol. 16: 1 gennaio 1861 - 12 giugno 1861. Roma: Istituto Storico Italiano per l'Età Moderna e Contemporanea, 1963.

7. Carbone, Gregorio, 'Benedizione della bandiera', in Dizionario militare compilato e dedicato alla maestà di Vittorio Emanuele II. Re d'Italia, ed. by Gregorio Carbone. Torino: Tip. V. Vercellino, 1863.

8. Chiaramonte, Umberto, Luigi Sturzo nell'ANCI. Soveria Mannelli: Rubbettino, 2004.

9. Commissione Reale Editrice (ed.), La questione romana negli anni 1860-1861: carteggio del Conte di Cavour con D. Pantaleoni, C. Passaglia, O. Vimercati, vol. II. Bologna: Zanichelli, 1929.

10. D’Amelio, Giuliana, Stato e Chiesa. La legislazione ecclesiastica fino al 1867. Milano: Giuffrè, 1961.

11. De Crescenzio, Nicola and Enrico Scialoja (eds.), Il Foro italiano: raccolta generale di giurisprudenza civile, vol. 9. Roma: Foro Italiano, 1884.

12. Della Cella, Michele, 'Bandiera'. Digesto Italiano, vol. V. Torino: Utet, 1890.

13. Fappani, Antonio, Il clero liberale bresciano negli anni dell'unità d'Italia. Brescia: Morcelliana, 1968. 
14. Ferrari, Silvio (ed.), Legislazione ecclesiastica e prassi giurisprudenziale. Gli abusi dei Ministri di culto tra laicizzazione della normativa e confessionalismo della magistratura. Padova: Cedam, 1977.

15. Frigyesi, Gustavo, L'Italia nel 1867: storia politica e militare corredata di molti documenti editi ed inediti e di notizie speciali, vol. I. Firenze: Tip. di G. Pellas, 1870.

16. Guasco, Maurilio, Storia del clero in Italia dall'Ottocento a oggi. Roma-Bari, Laterza, 1997.

17. Iozzelli, Fortunato, Roma religiosa all'inizio del Novecento. Roma: Edizioni di Storia e Letteratura, 1985.

18. Lupi, Maria, Il clero a Perugia durante l'episcopato di Gioachino Pecci (1846-1878) tra Stato pontificio e Stato unitario. Roma: Herder Editrice, 1998.

19. Miniero, Alessandro, Da Versailles al Milite ignoto: rituali e retoriche della vittoria in Europa (1919-1921). Roma: Gangemi, 2008.

20. Nocenti, Ferdinando (ed.), Prontuario di disciplina militare per uso della guardia nazionale mobile e sedentaria che servir può anche per l'armata, ossia, doveri generali e speciali dei militi e sott'ufficiali. Assisi: Tip. di D. Sensi, 1863.

21. Porciani, Ilaria, 'Lo Statuto e il Corpus Domini. La festa nazionale dell'Italia liberale'. Il Risorgimento. Rivista di storia del Risorgimento e di Storia contemporanea 47, 1-2 (1995).

22. Randazzini, Salvatore, Perchè i rivoluzionari vogliono andare a Roma: autorità e testimonianze. Milano: Tip. e Libr. Arcivescovile G. Agnelli, 1869.

23. Ridolfi, Maurizio, Le feste nazionali. Bologna: Il Mulino, 2003.

24. Roma (Municipio di), S.P.Q.R.: 27 marzo 1861, 27 marzo 1911. Roma: Tipografia Editrice Nazionale, 1911.

25. Scheiwiller, Vanni (ed.), Processo all'Altare della Patria. Atti del processo al monumento in Roma a Vittorio Emanuele II. Roma: Libri Scheiwiller, 1986.

26. Spadolini, Giovanni, Giolitti e i cattolici (1901-1914). La conciliazione silenziosa. Firenze: Edizioni della Cassa di Risparmio di Firenze, 1990 ( $\left.1^{\text {st }} \mathrm{ed} .1959\right)$.

27. Spataro, Giuseppe, I democratici cristiani dalla dittatura alla Repubblica. Milano: Mondadori, 1968.

28. Sturzo, Luigi, Nazionalismo e internazionalismo. Bologna: Zanichelli, 1971 ( $^{\text {st }}$ ed. 1946).

29. Taviani, Paolo Emilio, 'Filippo Meda e il cinquantenario di Civitas'. Civitas. Rivista mensile di studi politici 21, 5 (1970).

30. Tobia, Bruno, L'Altare della Patria. Bologna: Il Mulino, 2011 ( $1^{\text {st }}$ ed. 1998).

31. Viola, Orazio, Il tricolore italiano. Saggio bibliografico. Catania: Libreria Editrice C. Battiato, 1905. 
Valerio S Severino, PhD habil, is currently an MSCA scholar (CROSS project) at the University of Olomouc, the Czech Republic. He has carried out research projects at the Italian Accademia dei Lincei, the Polish Academy of Sciences, the Hungarian Academy of Sciences, the Luigi Salvatorelli Foundation, the Magyar Vallástudományi Társaság and the UPS, Research Institute for Politics and Government (Budapest). Author of the monographs La religione di questo mondo in Raffaele Pettazzoni (Bulzoni, 2009), and Documenting the History of Religions in the Hungarian Academy of Sciences (1950-1970). Letters, Reports and Requests across the Iron Curtain (Brill, 2021). His main fields of research are: the history of the academic studies of religions in Italy and Central Europe; comparative history of political and civil religions $\left(19^{\text {th }}-20^{\text {th }}\right.$ centuries); religion and art. Essays published in Italian and international journals: SMSR, Nuovi Argomenti, Religion, Journal of Religion in Europe, Numen, etc. 